\title{
Desenvolvimento das universidades e bibliotecas universitárias na idade média até à modernidade
}

Development of universities and academic libraries in the middle age to modernity

Fabiene Castelo Branco Diógenes, Murilo Bastos da Cunha

Universidade de Brasília

\section{RESUMO}

$\mathrm{O}$ ensaio analisa a origem das universidades, suas lutas pela autonomia, organização das estruturas administrativa e curricular e relata a existência das bibliotecas ligadas às universidades, desde a Idade Média até a Modernidade. No século XIX a educação é assumida pelo Estado, criando uma cobertura legal que garante às universidades a liberdade científica e pedagógica. A biblioteca universitária teve o seu desenvolvimento ao longo dos séculos, tentando acompanhar essas mudanças. Mas, é no decorrer desse século que alguns serviços e foram surgindo os entendimentos da relação da biblioteca com a universidade. Entretanto, foi a partir da Segunda Guerra que o ensino começa a ter característica de atividade de massa, e a biblioteca universitária se torna uma parte importante na universidade. Cresce a ênfase ao acesso às coleções, há financiamento do Estado para desenvolvimento de coleções e estruturação de suas bibliotecas, dão-se início às atividades de cooperação e de automação. Estas começam a mudar a forma como são oferecidos os serviços e produtos das bibliotecas universitárias. A partir de 1970, as novas tecnologias penetram nessas áreas, e as universidades e suas bibliotecas são afetadas por tais tecnologias. Propostas de reformas surgem gerando novos desafios para estas duas instituições centenárias.

PALAVRAS-CHAVE: Biblioteca universitária. Idade Média. Modernidade.

\section{ABSTRACT}

The essay analyzes the origin of universities, their struggles for autonomy, administrative organization and curricular structure and an account of the existence of libraries linked to universities, from the Middle Age to Modernity. In the nineteenth century, education is assumed by the State and provides a legal cover to universities scientific and pedagogical freedom. The university library had its development over the centuries, trying to keep up with changes. However, it is during this century that some service and were emerging the understanding of the relationship between the university library and the university. However, it was after the Second World War, that teaching begins his walk to the mass school, and the university library becomes an important part of the university. There is a growing emphasis on access for collections, state funding for collections development and structuring of their libraries, cooperation and automation activities. These changes begin to transform the way products and services of academic libraries. From 1970, new technologies penetrate in these areas and universities and their libraries affected due to such technologies. Reform proposals emerge generating new challenges for these two centennial institutions.

KEYWORDS: Academic library. Middle Age. Modern Age.

\section{Correspondência}

${ }^{1}$ Fabiene Castelo Branco Diógenes

Universidade de Brasília.

Brasília, DF.

Email: fabienecastelo@gmail.com

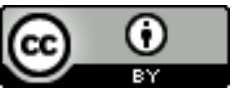

JITA: DD. Academic libraries. 


\section{INTRODUÇÃO}

Este artigo analisa a origem das universidades, suas lutas pela autonomia, organização da estrutura administrativa e curricular e apresenta um relato sobre a existência das bibliotecas ligadas às universidades, desde a Idade Média até a Modernidade.

Ao iniciar este texto é importante apontar que a Idade Média, segundo Andery (2002), tem como referência temporal o período que vai do século V ao XV. Além disso, abordar-seão as características da sociedade nesse período, época em que se configuram muitas das relações sociais e de poder, e surgem os locais do conhecimento, especialmente o aparecimento das universidades, e, timidamente, o das bibliotecas universitárias.

Nos últimos séculos do feudalismo, notadamente no século XIII, época em que as universidades foram surgindo no Ocidente, a sociedade feudal se modificou, passando de uma economia de troca para monetária. Houve aumento na divisão do trabalho, maior interdependência humana, desenvolvimento das cidades, origem dos tributos, surgimento dos intelectuais ou homens do saber da Idade Média (ELIAS, 1993; LE GOFF, 1995; VERGER, 1999; ANDERY et al., 2002; GOODY, 2008, p. 246).

Segundo Andery et al. (2002) e Elias (1993) verificou-se um aumento populacional, caracterizado como um dos principais motores da mudança na estrutura das relações humanas e das instituições a elas correspondentes. Este aumento da população tem relação com o ápice do movimento de migração, intensificação do comércio e o consequente crescimento das cidades, o que foi conferindo maior complexidade a esta sociedade do século XVIII em relação à sociedade dos séculos anteriores.

A sociedade feudal, de acordo com Elias (1993), gradativamente foi substituída pela sociedade absolutista, aquela em que um único dos grandes senhores feudais - o rei assumiu a oportunidade de controlar um governo mais estável em uma região que abrangia muitos territórios, um "Estado". É a essa sociedade absolutista que se deve parte da herança de padrões de civilização. "Nesta sociedade aristocrática [...] foram modeladas, ou pelo menos, preparadas parte dessas injunções e proibições que ainda hoje se percebem" (idem, 1993, p. 18-19).

No século XII, o desenvolvimento das cidades, simultaneamente ao surgimento das cortes dos grandes senhores feudais, significou um aumento na divisão de trabalho e interdependência das pessoas. As cidades se constituem em um dos traços essenciais da nova paisagem intelectual da Cristandade Ocidental, em centros de irradiação na circulação dos homens, tão plenas de ideias quanto de mercadorias, lugares de trocas, mercados e encruzilhadas do comércio intelectual juntamente às novas instituições que constituem um espaço comum a toda a Cristandade (ELIAS, 1993; LE GOFF, 1995; ANDERY et al, 2002; GODDY, 2008). 
Nasce, também, com as cidades, o que vem se constituindo desde os séculos X e XI, em o intelectual da Idade Média, que se torna perceptível no século XII. Mas não há consenso em torno do surgimento e do conceito de intelectual. Para Le Goff (1995) os intelectuais da Idade Média são os novos tipos de sócio-profissionais que emergem nos séculos XII e XIII, nas cidades, cuja profissão é escrever e/ou ensinar. Os homens do saber, estudados por Verger (1999), especialmente os dos séculos XIV e XV, são indivíduos que teriam certo tipo e nível de conhecimento e competências técnicas advindas dos saberes adquiridos.

Em uma sociedade ideologicamente controlada pela Igreja e cada vez mais enquadrada politicamente pela burocracia laica e eclesiástica, os intelectuais da Idade Média são, antes de tudo, de acordo com Le Goff (1995), fiéis servidores da Igreja e do Estado.

Além das formas sociais, como as cidades, e os intelectuais que assumem características deste período, instituições como o Estado também adquirem contornos próprios dessa época. A origem do Estado é controvertida. Uns consideram que ele é uma instituição que existiu desde a antiguidade, outros consideram que começou a existir na modernidade. Quem considera o Estado como a polis grega vê mais continuidade do que descontinuidade, ou seja, o Estado existiu desde aquela época. Segundo Bobbio (1987) quem considera como elemento constitutivo do Estado o aparato administrativo e o cumprimento de certas funções que apenas o Estado Moderno desempenha, deverá sustentar que a polis grega não é um Estado, que a sociedade feudal não tinha um Estado.

Na concepção de Bobbio (1987), foi durante os séculos medievos que se elaborou aquela concepção jurídica do Estado, que não era estranha à teoria política romana. Elias (1993) vai em direção semelhante quando mostra que os processos de transformação do Estado e o de centralização encontraram sua primeira expressão visível na forma absolutista de governo, cuja sociogênese ocupa posição decisiva no processo global da civilização.

Elias (1993) define o Estado como o poder de controlar um governo mais estável em uma região que abrangia muitos territórios, e defende que na sóciogênese do Estado (época do absolutismo), a luta foi pela centralização e controle do governo, tendo o processo de crescente centralização da sociedade sido expresso pela primeira vez na forma absolutista de governo.

Para Andery et al. (2002), outra forma social que teve influência enorme na Idade Média foi a Igreja. Além de seu poderio econômico, possuía uma estrutura organizada de forma centralizada e hierarquizada que lhe possibilitou, ainda, mais hegemonia na Idade Média. Na vida intelectual, a Igreja controlava não só a veiculação do conhecimento, mas também a sua produção. Nesse contexto, a produção do conhecimento científico, que começou a intensificar-se no século XI, teve um caráter mais prático que explicativo. Andery e outros (2002) comentam que quanto às explicações dadas aos fenômenos, estas estão impregnadas de valores defendidos pela Igreja. 
Elias (1993) atribui à Idade Média fases e setores altamente dinâmicos que continuam em direção aos tempos modernos, estágios de expansão, de aumento de divisão de trabalho, de transformação social e revolução, de aperfeiçoamento dos instrumentos de trabalho, mesmo que o ritmo do desenvolvimento social tenha se acelerado acentuadamente depois da Idade Média.

Essa posição de Elias (1993) é vista de outra maneira por Goody (2008), que não aceita o período medieval na Europa como um estágio "progressivo" na avaliação do desenvolvimento da sociedade, pois considera é exagero ver o feudalismo como período de progresso em relação à produção irrigada, às cidades permanentes e às sociedades orientais. Para Elias (1993), as mudanças no processo da civilização não foram realizadas racionalmente, mas pela ordem dos planos e impulsos entrelaçados no curso da história. Essas mudanças observadas sob a ótica da dinâmica dos processos sociais mostram que a dinâmica da interdependência movimenta as transformações sociais, mantém, no presente e no passado, o homem em movimento e pressiona na direção de mudanças em suas instituições e na estrutura global de suas configurações.

Se considerarmos as mudanças que a sociedade assume nas transformações sociais (sociogênese) das formas de governo, economia e indivíduos, que a construção do conhecimento está relacionada ao surgimento de instituições que transmitem e divulgam esse saber, como eram os templos e a academias na antiguidade, as escolas, universidades na Idade Média, podemos concordar com Le Goff (1995) quando afirma que o século XIII foi o século das corporações e também com Elias (1993), que afirma que essa não foi uma época de estagnação. Entretanto, tem o outro lado abordado por Goody (2008) para quem, enquanto a Idade Média cresceu na manufatura, no comércio, negligenciou o declínio das culturas letradas bem como da sociedade urbana e suas atividades associadas.

Numa linha similar de pensamento, Andery et al. (2002) observam que, embora a produção científica, no que se refere às questões práticas, tenha sido superior à fase anterior do período, foi bastante limitada neste período especialmente pelo papel que a Igreja desempenhou neste período medieval. Houve estímulo à produção de inovações técnicas e incorporações de inovações que vêm de outros povos, como o oriental.

É dessa época da Idade Média que pode se resgatar em Elias (1993) o conceito de rede, interdependência que influiu na gênese e desenvolvimento das instituições e cujo crescimento da interdependência, segundo esse autor, influiu para que instituições relativamente estáveis pudessem ser estabelecidas. Seus conceitos de interdependência e configurações permitem à sociedade lidar com uma rede de relações como conflitos, engajamento, relações de poder. 


\section{CRIAÇÃO E ORGANIZAÇÃO DAS UNIVERSIDADES NA IDADE MÉDIA}

Embora seja frequentemente tão obscuro como as outras corporações, o século XIII é considerado como o das universidades, porque é o das corporações. As universidades, na análise de Le Goff (1995), organizam-se lentamente, mediante sucessivas conquistas, e seus estatutos sancionam essas conquistas tardiamente.

As universidades apareceram em Bolonha, em Paris, em Montpellier e em Oxford nos primeiros anos do século XIII, derivadas de escolas pré-existentes e tinham em comum serem organismos autônomos de natureza corporativa. Ser autônoma significava, de acordo com Verger (1999), poder dotar-se de estatuto e organizar livremente aquilo que era a razão de ser da cooperação universitária: o ensino, os programas, a duração dos estudos, as modalidades de exames, a colação de graus. Depois de Bolonha e Paris, vieram, segundo Burke (2003), as universidades de Salamanca (1219), Nápoles (1224), Praga (1347), Pavia (1361), Cracóvia (1364), Louvain (1425) e muitas outras.

Para autores como Burke (2003) e Le Goff (1995), na Idade Média, as universidades concentravam-se na transmissão do conhecimento e não em sua descoberta. A sua característica essencial no século XIII era ser uma corporação eclesiástica. Isso explica sua ambiguidade na sociedade e suas crises de estrutura, pois ainda que em seu contingente estivesse presente um número cada vez maior de leigos, os universitários eram considerados como clérigos e dependiam de jurisdições eclesiásticas.

O sistema universitário permitia uma real ascensão social, que se fazia por meio do exame. Os estatutos universitários regulavam a organização dos estudos (LE GOFF, 1995). As universidades conhecem períodos de organização administrativa e dos estudos, de modelos diversos, de crescimento, de importância muito desigual, de influência na formação das elites letradas europeias, de integração às novas estruturas do Estado. Passam pelo dinamismo criador das universidades, pelo peso do ensino escolástico, pelos custos elevados dos cursos, pela desorganização dos mesmos, pela ausência de professores, mas passam, também, por uma renovação de doutrinas, e seu peso social e político cada vez mais reconhecido. Nos finais do século XV, passam a ter uma importância maior no seu papel social. Le Goff (1995) e Verger (1999) apontam que, nesse período, as bibliotecas universitárias se mostram em estágio muito incipiente.

Neste cenário, as universidades cresceram e se organizaram. Existiam por volta de quinze studia generalia em 1300 e mais de vinte em 1346 (VERGER, 1999). Studia generalia é o termo que se usava na Idade Média para se referir também à Universidade. Para esse autor, o elemento central do sistema educativo medieval era constituído, a partir do século XIII, pelas universidades, ou, como se dizia, pelos studia generalia.

As universidades, antes do século XIV, nasceram e se desenvolveram sem apoio dos poderes externos. A partir do século XV, estes poderes tomaram esta iniciativa, pois o papado

\begin{tabular}{|c|c|c|c|c|c|}
\hline (C) RDBCI: Rev. Digit. Bibliotecon. Cienc. Inf. & Campinas, SP & $\mathrm{v} .15$ & n.1 & p. 99-129 & jan./abr. 2017 \\
\hline
\end{tabular}


não faria tanta interferência, como os poderes laicos, embora tarde, o fariam para garantir o estatuto clássico do studium generalia. A vontade política não era suficiente para garantir o sucesso do studium generalia. Era necessário existir um contexto favorável, quer seja por uma tradição escolar pré-existente, quer seja por uma demanda social suficientemente forte (VERGER, 1999).

Ao longo dos séculos XIV e XV as universidades perderam o seu caráter internacional, cuja causa principal se dá pela fundação de numerosas instituições novas. Essa multiplicação de instituições, segundo Le Goff (1995), serviu para fazer desaparecer ou reduzir um recrutamento internacional dos mais importantes e arruinar o sistema de nações, tão significativo dentro das universidades, visto que eram peças fundamentais de sua estrutura.

Por volta do século XIV, o fenômeno universitário era principalmente mediterrâneo. Os studia generalia meridionais inspiravam-se, quase sempre, no modelo bolonhês, em que os estudantes eram responsáveis pela organização e gestão da universidade e estavam sob a supervisão da Igreja, mas essas universidades meridionais já possuíam, pelo conteúdo de seu ensino, uma forte colaboração laica. Na metade do norte da Europa a situação era diferente. $\mathrm{O}$ modelo, de acordo com Verger (1999), era o da "universidade dos mestres", em que cada professor tinha autonomia.

Apesar das constatações por vários autores de que as instituições no Islã não tinham status de universidade, Goody (2008) afirma que o ensino superior sempre existiu, tanto no Ocidente quanto no Oriente. $\mathrm{O}$ autor defende que o Islã teve importantes instituições de educação superior religiosa e legal e que, talvez, o mais importante seja dizer que essas instituições eram quase que exclusivamente devotadas aos estudos religiosos, ao passo que na Europa, apesar de a religião inicialmente ter dominado, permitiu-se que outras matérias se desenvolvessem dentro dos domínios da universidade.

No processo de extinção do sistema de nações dentro da universidade, ao longo dos séculos XIV e XV, as universidades se integram às novas estruturas do Estado. Um Estado que reivindica seus direitos sobre a vida social e tem os poderes legislativo, executivo e jurídico (LE GOFF, 1995).

Assim, a universidade favoreceu o desenvolvimento do individualismo político no final da Idade Média, mas não era o individualismo o que de fundamental existia na experiência humana adquirida na universidade, mas a experiência da sociabilidade universitária, integração poderosa da clientela que estruturava toda aquela sociedade. Portanto, de acordo com Verger (1999), a vida universitária era a aprendizagem do privilégio, mas era, também, a aprendizagem da responsabilidade. 


\section{A BIBLIOTECA UNIVERSITÁRIA NA IDADE MÉdia E SUA PRECÁRIA EXISTÊNCIA}

As universidades e bibliotecas integraram, na Idade Média, um conjunto de locais, onde surgiram, prosperaram, e foram divulgados os conhecimentos que Burke (2000, p. 5456) chamou de geografia do conhecimento. Para o autor (p. 57), o mosteiro, a universidade e o hospital e, mais tarde, o laboratório, a galeria de arte, a livraria, a biblioteca, o anfiteatro de anatomia, o escritório e o café eram sedes tradicionais de conhecimento, em nível micro.

Na França, Verger (1999) identificou, entre as primeiras bibliotecas universitárias, constituídas somente de algumas dezenas de volumes, as de Orléans (1411), de Avignon (1427), de Poitiers (1446) e as das faculdades de Medicina e de Direito Canônico de Paris (1395 e 1475). Foi quase exclusivamente em Caen que a realização de um inventário em 1515 identificou uma coleção de 227 volumes. Outras universidades eram mais "bemdotadas" (expressão do autor), como a de Oxford, cuja biblioteca, fundada em 1412, se desenvolveu principalmente graças às doações do duque de Gloucester, com 280 livros, entre 1439 e 1447.

Ollè (1971) refere-se ao início da biblioteca da Universidade de Oxford, no século XIV, como uma coleção de livros em uma sala contígua em St. Mary's Church, seguida de uma melhor acomodação, conhecida como Duke Humfrey, no século XV. Depois, Thomas Boddley (1545-1613) ofereceu a reconstrução da biblioteca e a supervisionou, concebendo-a como um instrumento religioso, pois continha obras protestantes e católicas (ESCOLAR SOBRIÑO, 1990).

Além das bibliotecas privadas, com número reduzido de livros, Verger (1999) identifica as bibliotecas universitárias como um dos três tipos de bibliotecas institucionais da época, além das principescas e das bibliotecas das catedrais. Essas bibliotecas, segundo o mesmo autor, só excepcionalmente eram consultadas por homens do saber. Eles contavam, antes de tudo, com suas pequenas bibliotecas pessoais. Era apenas a título excepcional, e para consultar alguma obra na sua versão original, é que eles iriam a uma dessas bibliotecas. As bibliotecas universitárias eram, "frequentemente, muito menos importantes e praticamente não existiam antes do século XV” (idem, 1999, p. 114).

\section{A UNIVERSIDADE E A BIBLIOTECA UNIVERSITÁRIA NA MODERNIDADE}

Neste tópico, apresenta-se o cenário das universidades e bibliotecas universitárias modernas, a partir do século XVII e até início do século XXI, com enfoque no pensamento racional, na formação do Estado moderno, no capitalismo e nas rápidas e intensas mudanças que ocorreram no período entre o século XX e início do século XXI, em relação ao papel do Estado, do capitalismo e das novas tecnologias.

\begin{tabular}{|c|c|c|c|c|c|}
\hline (C) RDBCI: Rev. Digit. Bibliotecon. Cienc. Inf. & Campinas, SP & V.15 & n. & p. 99-129 & jan/abr. 2017 \\
\hline
\end{tabular}


O termo modernidade será adotado, de acordo com Giddens (2002, p. 21) que o emprega para referir-se "às instituições e modos de comportamento estabelecidos depois do feudalismo, mas que no século XX se tornaram mundiais em seu impacto". Para o autor, modernidade é um estilo de vida ou organização que emergiu na Europa a partir do século XVII, mas, especialmente, uma época em que elementos de descontinuidades ${ }^{1}$ como o ritmo, escopo das mudanças e urbanismo são os elementos que separam as instituições modernas das ordens sociais tradicionais.

Giddens (2002) considera a primeira fase do modernismo, do século XVII ao XIX, época em que havia o controle das relações sociais em um mesmo espaço, e a segunda fase, a da modernidade tardia ou alta modernidade, a partir do século XX, época em que há um esvaziamento do espaço e tempo, com deslocamento das relações sociais dos contextos locais por meio de partes indeterminadas de tempo e espaço. A abordagem conceitual desse autor em relação às características básicas da modernidade serve, nesta revisão, de janela conceitual para dar luz neste trabalho a este complicado conceito de modernidade.

Para Giddens (1991) o mundo moderno é extremamente dinâmico. Este dinamismo, que é inerente às instituições modernas, se constitui de três elementos que permitem a explicação dele: a) tempo e espaço: condição de articulação das relações sociais ao longo de amplos intervalos de espaço-tempo, incluindo sistemas globais; b) mecanismos de desencaixe: que captam o deslocamento das relações sociais dos contextos locais e sua rearticulação através das partes indeterminadas do espaço-tempo; c) reflexividade: que difere do monitoramento reflexivo de toda atividade humana e se refere à suscetibilidade da maioria dos aspectos da atividade social e das relações materiais.

Em relação ao conhecimento científico, segundo o autor, a reflexividade "solapa a certeza do conhecimento, mesmo nos domínios centrais da ciência natural. A ciência depende não da acumulação indutiva de demonstrações, mas do princípio metodológico da dúvida" (idem, 1991, p. 26).

Essas características básicas das instituições modernas, incluindo a ação de desencaixe e reflexividade evidenciam que a modernidade é inerentemente globalizante.

\footnotetext{
${ }^{1}$ As descontinuidades que separam as instituições modernas das ordens sociais tradicionais são: a) ao ritmo da mudança - civilizações tradicionais podem ter sido mais dinâmicas em outros sistemas pré-modernos, mas a rapidez da mudança em condições da modernidade é extrema. Se isto é, talvez, mais óbvio no que toca a tecnologia, permeia todas as outras esferas; b) escopo da mudança - diferentes áreas do globo são postas em interconexão e ondas de transformação social atravessam toda a terra; c) a natureza intrínseca das instituições modernas - algumas instituições não se encontram em períodos precedentes, como o sistema político do estadonação; outras têm continuidade enganosa com ordens sociais pré-existentes como, por exemplo, a cidade cujos modernos assentamentos incorporam os locais das cidades tradicionais. O urbanismo moderno é ordenado segundo princípios diferentes dos que estabelecera a cidade pré-moderna em relação ao campo em períodos anteriores. O autor pensa que ao tentar explicar a natureza das sociedades modernas, têm que captar as características específicas do estado-nação e tentar entender a questão da ordem, de como se dá nos sistemas sociais a ligação tempo e espaço (GIDDENS 1991, p. 15 -16; 22).

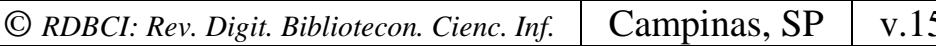

n. 1

p. $99-129$

jan./abr. 2017
} 
A globalização da atividade social é de certa maneira um processo de desenvolvimento de laços genuinamente mundiais, como os envolvidos no sistema global de Estados-nações ou na divisão internacional do trabalho. A globalização diz respeito à interseção entre a presença e a ausência, ao entrelaçamento de eventos e relações sociais "à distância" com contextualidades locais (idem, 2002, p. 27).

Continuando, Giddens (2002) aponta que a alta modernidade introduz riscos que as gerações anteriores não tiveram que enfrentar. A influência de acontecimentos distantes sobre eventos próximos, e sobre o eu se torna cada vez mais comum. As mídias impressas e eletrônicas desempenham um papel central. Reconhece-se, concordando com esse autor, que na alta modernidade a influência de acontecimentos distantes sobre eventos próximos, e sobre o eu, se torna cada vez mais comum. Alcança-se um período em que as consequências da modernidade estão se tornando mais radicalizadas e universalizadas que antes.

Não serão tratadas neste trabalho, as complexas discussões sobre conceitos e limites da modernidade e pós-modernidade, para o que se sugere leituras de obras de autores como Giddens (1991), Lyotard (1985), Harvey (1989), dentre outros.

Para o capitalismo, será utilizada a periodização de Boaventura de Sousa Santos (1994 apud MAGALHÃES, 2004, p. 72) que assim o divide: século XIX - capitalismo liberal; capitalismo organizado - últimas décadas do século XIX até 1960; capitalismo desorganizado - finais dos anos de 1969 e início dos anos de 1970.

\section{CONTEXTO SOCIAL, ECONÔMICO E POĹTICO DA MODERNIDADE}

No final do século XVI e início do século XVII, surgiu, segundo Magalhães (2004), uma nova forma de viver e pensar na Europa, diferente da do período medieval, em que as sociedades tinham se organizado em torno da supremacia de Deus e da centralidade de sua representação secular, a Igreja: os reis governavam as sociedades por vontade de Deus e com a benção da Igreja e a vida da sociedade e das pessoas era governada por uma envolvente narrativa religiosa.

Para Abrantes (1998), Japiassú (2001) e Soares (2001) ocorreram mudanças de imagens da natureza e da ciência no século XVII e a Ciência Moderna, que se constituiu com a Revolução Científica do século XVII, correspondeu a um processo de mudança gradual e geral no clima intelectual e cultural da Europa Ocidental em meados dos séculos XVI e XVII.

A centralidade do pensamento nesse período era na razão que substituiu o lugar que Deus ocupava na Idade Média (MAGALHÃES, 2004). Essa mudança de centralidade do pensamento deu origem a uma nova concepção da relação Deus-Natureza que, para Abrantes (1998), foi condicionante para a nova concepção da Ciência. 
Afirmou-se, assim, a partir do século XVII, uma forte tendência à adoção de uma imagem mecânica da natureza na construção de teorias científicas, particularmente no domínio da Física, após prevalecer, por toda a Idade Média, as metáforas do organismo da Antiguidade. A máquina, de acordo com Abrantes (1998) é um modo de apresentar esse programa mecanicista de pensar a natureza.

O pensamento social do século XVIII e da primeira metade do século XIX refletiu em sua maioria as ideias, interesses e necessidades da classe burguesa e expressou, embora de diferentes formas e em graus variados, três valores básicos da sociedade burguesa: a liberdade, o individualismo e a igualdade. A noção de liberdade se expressava nas ideias dos economistas clássicos, que defendiam o livre comércio e a livre concorrência e a suspensão de todas as limitações às atividades comerciais e industriais impostas pelo mercantilismo; a economia deve se fazer por si mesma segundo leis naturais (ABRANTES, 1998; ANDERY et al., 2002).

Para Soares (2001) a concepção científica do século XVIII foi aquela em que os cartesianos reconheceram a superioridade da perspectiva newtoniana e procuraram incorporar a experimentação, afirmando-se uma nova concepção da verdade científica obtida por meio de prova experimental.

Japiassú (2001) comenta que a Ciência passou a funcionar segundo normas de um racionalismo quantificado e a concepção da natureza passou a ser concebida para obedecer a uma ordem racional determinada por uma filosofia experimental, o que se refletiu nas demais formas de saber. A confiança que todos depositavam na nova ciência, no final do século XVIII, era praticamente ilimitada.

O século XIX, na opinião de Hobsbawm (1995), foi um período de progresso material, intelectual, moral, quase ininterrupto de melhoria nas condições de vida civilizada. No início desse século, as atividades de pesquisa começaram a se sistematizar e a se institucionalizar e tornou-se visível que o progresso técnico acelerava o progresso científico. Assim, para Japiassú (2001) e Szmrecsányi (2001), essa interação entre ciência e tecnologia faz surgir inovações que foram as responsáveis pela materialização da Segunda Revolução Industrial na Europa e nos Estados Unidos durante a última metade do século XIX.

As relações entre ciência, tecnologia e economia tornaram-se visíveis no decorrer do século XIX, em parte pela transformação das ciências e das técnicas em atividades sociais autônomas para atividades diferenciadas (SZMRECSÁNYI, 2001).

No final do século XIX, de acordo com Andery et al. (2002), os conhecimentos científicos eram desenvolvidos para criar novas indústrias e, finalmente, no século $\mathrm{XX}$, encontrava-se em pleno desenvolvimento da indústria científica. Ciência e produção expressam, cada vez mais claramente, a inter-relação e as influências mútuas que as unem. 
O Estado e a sociedade, no século XIX, estavam se pautando pelos valores da razão, do debate público, da educação, da ciência e da capacidade de melhoria da condição humana (HOBSBAWM, 1995).

Ao estudar a formação e desenvolvimento do Estado, Elias (1993) mostra que estas esferas se movimentam e se interdependem em um processo que no âmbito do Estado as lutas são travadas pelo poder, mas mostra, também, que impulsos emocionais e racionais de pessoas isoladas constantemente se entrelaçam e determinam o curso da mudança histórica.

Max Weber (1994) utilizou o conceito de racionalidades na evolução da história e para chegar ao arcabouço conceitual da organização do Estado moderno, analisou os seus funcionários, as formas de poder da administração pública, a burocracia, a ação política nesta esfera, os tipos de dominação, padronização dos tipos ideais, dentre outros. Do ponto de vista sociológico de uma associação política, a coação física é o meio específico que permite definir o Estado (idem, 1999).

Weber, segundo Nobre (2005), tratou da constituição do Estado como estrutura de dominação, alicerçada no funcionamento burocrático, na submissão dos mandatários às leis constituídas e, principalmente, na concentração bélica e na monopolização do direito ao uso da violência legítima.

O Estado-nação é, para Giddens (2002), uma das formas sociais mais importantes produzidas pela modernidade. Na visão deste autor, o Estado-nação, como entidade sociopolítica contrasta com a maioria dos tipos de ordem tradicional, pois desenvolve-se como parte de um sistema de estados-nações, tem formas específicas de vigilância e territorialidade, monopoliza o controle efetivo sobre os meios da violência, segue uma característica mais geral da modernidade, que é a ascensão da organização.

No seu esforço de compreensão da formação do Estado no capitalismo, Weber (1999) mostra que a luta entre os Estados nacionais pelo poder criou maiores oportunidades para o capitalismo moderno ocidental, e foi no Estado racional baseado no Direito Racional e na burocracia de profissionais que, na análise de Weber, o capitalismo pôde se desenvolver (OPUSZKA, 2011).

O capitalismo é visto por Giddens (2002) como um dos eixos institucionais de como a modernidade pode ser entendida, além do eixo do mundo industrializado, no que se refere ao uso generalizado da força material e do maquinário nos processos de produção. O estadonação e o capitalismo, em termos de agrupamento institucional têm para Giddens (1991) um significado especial no desenvolvimento da modernidade. Para esse autor, a produção capitalista sistemática e o estado-nação, estreitamente relacionadas, têm se projetado, principalmente pelo poder que geraram, promovendo a aceleração e expansão das instituições modernas. 
Castells (2005) aponta que a tecnologia presente em todos os períodos da história tem no século XX seu diferencial nas novas tecnologias que, entre meados dos anos de 1970 e 1990, difundiram-se pelo mundo numa velocidade extraordinária e com uma característica de aplicação imediata no próprio desenvolvimento da tecnologia gerada, conectando o mundo por meio da tecnologia da informação.

A história mostra que no século XX as concepções que embasam áreas e setores da sociedade moderna são fundadas na razão, contando com sistema de desenvolvimento econômico e social na fase do capitalismo organizado, tendo um Estado moderno estruturado e com uma revolução tecnológica de dimensões nunca vistas antes.

Como pode se constatar, o século XX foi, segundo Ianni (1999), caracterizado por guerras e revoluções, golpes e contragolpes, muitas vezes, envolvendo domínios de imperialismos norte-americano, inglês, alemão e francês, italiano, japonês e outros.

Especialmente, no período de 1914 a 1991, que Hobsbawn (1995) denominou de "Breve Século XX" (a partir da Primeira Guerra Mundial até o colapso da URSS, em fins da década de 1980 e início da década de 1990), presenciou-se um período de grandes catástrofes, desenvolvimentos surpreendentes e perda de rumos, que o autor periodiza em três eras: Era da Catástrofe (de 1914 até depois da Segunda Guerra Mundial), Era de Ouro (depois da Segunda Guerra Mundial até 1970) e Era do Desmoronamento (a partir de 1970 até a década de 1990).

$\mathrm{Na}$ Era da Catástrofe, houve colapso dos valores em instituições da civilização liberal que já tinham avançado por todo o século XIX, como: descontinuidade da ditadura, compromisso com governos e assembleias representativas livremente eleitas, um conjunto já aceito de direitos e liberdades dos cidadãos (idem, 1995).

$\mathrm{Na}$ Era de Ouro, houve um período de extraordinário crescimento econômico e transformação social, que mudou de maneira profunda a sociedade humana mais que qualquer outro período de brevidade comparável. Para Hobsbawm (1995), a pesquisa e Desenvolvimento, neste período, tornaram-se fundamentais para o crescimento econômico.

Houve, ainda, na Era de Ouro uma profunda reestruturação e reforma do capitalismo que produziu uma economia mista. O mais impressionante nesse período, segundo Hobsbawm (1995) foi a dimensão em que o aumento do desenvolvimento econômico que parecia ser movido pela revolução tecnológica produziu na transformação da vida cotidiana das pessoas; na descoberta da produção da complexa tecnologia e na exigência de pouca mão de obra, ou sua substituição, causada pelo surgimento das novas tecnologias. 
Foram os anos de 1970, de acordo com Castells (2005), a época provável do nascimento da revolução tecnológica e de uma linha divisória na evolução do capitalismo, que vai coincidir com o início da Era do desmoronamento, a partir de 1973 até 1990, quando, segundo Hobsbawm, (1995), o mundo perdeu suas referências e entrou em crise. Segundo Magalhães (2004, baseado em Santos), 1970 marca o início do capitalismo desorganizado.

Após 1974, os keynesianos (defendiam o Estado de bem-estar) e os neoliberais defendiam o controle cada vez menor de assuntos, por parte do Estado. Estabeleceu-se uma economia transnacional que foi enfraquecendo uma grande instituição, praticamente universal, até 1945: o Estado-nação territorial (HOBSBAWM, 1995).

Sob o neoliberalismo ${ }^{2}$, a dissociação crescente e generalizada entre o Estado e a sociedade civil torna o Estado muito mais comprometido com tudo que é transnacional, mundial, global, reduzindo-se o seu compromisso com as inquietações, reivindicações ou tendências da sociedade civil. Para Ianni (1999), amplos setores desta sociedade são desafiados a seguirem a lógica do mercado e com a força das corporações transnacionais há dificuldade ou inviabilidade da capacidade de negociação das diferentes categorias de assalariados.

Segundo Ianni (idem, 1999), no século XX, para se formular e colocar em prática projetos nacionais, era preciso muitas negociações, lutas, conflitos, frustrações e realizações, pois estas propostas se defrontavam com interesses e tradições das oligarquias comprometidas com economias primárias exportadoras, empenhadas em manter o modelo agrário-comercial, com as estruturas de poder comprometidas com os monopólios políticos e econômicos.

A Guerra Fria entre EUA e URSS, que ocorreu do período Pós-Guerras até 1987 e terminou na Conferência da Cúpula de Washington, levou a falência das bases que sustentavam a estrutura internacional e as estruturas dos sistemas internos mundiais (HOBSBAWM, 1995).

Para Ianni (1999), depois da Guerra Fria, a partir de 1987, intensificou-se o desenvolvimento do capitalismo e um novo ciclo de globalização do capitalismo, que se constituiu no cenário no qual o Fundo Monetário Internacional (FMI), o Banco Mundial (BIRD), a Organização Mundial do Comércio (OMC) e as corporações transnacionais pressionaram os Estados nacionais a promoverem reformas políticas, econômicas e

\footnotetext{
${ }^{2}$ Neoliberalismo - teoria que teve sua origem no liberalismo clássico, no século XII, postula que as atividades econômicas devem ser conduzidas pelo mercado para maximização do bem-estar da sociedade. Seus adeptos defendem o estado mínimo e consideram que as políticas públicas são as principais responsáveis pela crise que perpassa as sociedades, pois afetam a ordem econômica social e moral porque tende a desrespeitar os princípios da liberdade e individualidade (AZEVEDO, 2004, p. 9-12) Em um Estado com políticas neoliberais os fornecedores de serviços, inclusive na área educacional, passam a competir livremente em busca de clientes pois, a princípio, o aumento da oferta proporciona maior qualidade (MENEGHEL, [2002?]).
} 
socioculturais que envolviam as instituições jurídico-políticas destinadas a favorecerem a dinâmica das forças produtivas e relações capitalistas de produção.

Continuando, Ianni (1999) aponta que as pressões destinadas a promover a reestruturação do Estado foram as mais diversas: desestatização e desregulação da economia mundial, promoção da privatização de empresas produtivas estatais e dos sistemas de saúde, educação e previdência. Os mercados foram abertos, conquistas sociais foram sendo reduzidas ou eliminadas a partir das palavras de ordem: mercado, produtividade, competitividade.

Neste contexto, o que estava em causa na reestruturação do Estado destinado a criar o Estado mínimo e decretar a formação de mercados emergentes era a substituição do projeto nacional, capitalista ou socialista, para o projeto do capitalismo transnacional, transnacionalizado, administrado do alto e de fora (idem, 1999).

No período de 1980 e início de 1990, o mundo capitalista se defrontou com problemas da época do entre guerras, que a Era de Ouro parecia ter eliminado: desemprego em massa, depressões cíclicas severas, desencontros entre receitas e despesas do Estado e o fosso era cada vez maior entre pobres e ricos (HOBSBAWM, 1995).

Nesta época, várias transformações ocorreram: quase todos os países do Terceiro Mundo se endividaram profundamente, sendo que em 1990, no Brasil, no México e na Argentina, grandes devedores internacionais, ocorreu a morte do campesinato, e, ao seu lado, o crescimento de ocupação que exigiam a educação secundária e superior; o número de estudantes aumentou muito; as classes operárias, após a década de 1990, foram vítimas das novas tecnologias; aumentou o número de mulheres no mercado de trabalho e no acesso à educação superior; aconteceu uma revolução cultural expressa pelas mudanças na família, nas estruturas de relações entre os sexos e gerações (idem, 1995).

As empresas em todo o mundo reagiram ao declínio da produtividade e adotaram novos caminhos, como da inovação tecnológica e descentralização organizacional. Para Castells (2005, p. 136-137) "as novas tecnologias de informação foram instrumentos essenciais". Essas tecnologias já eram notadas antes da década de 1940, mas só na década de 1970 difundiram-se amplamente, culminando na década de 1990 com a criação dos computadores atuando em rede (idem, 2005).

Para Giddens (2002) a era moderna se depara com uma característica indiscutível que a separa de qualquer período anterior, que é o seu extremo dinamismo em um mundo muito rápido, quer no ritmo da mudança social, quer na amplitude e profundidade dessa mudança que afeta práticas e modos de comportamento pré-existentes.

No final do milênio, existia uma tecnologia com bases em avançadas teorias e a pesquisa científica, que dominou a grande explosão econômica da segunda metade do século 
XX (HOBSBAWM, 1995). O sistema de tecnologia, segundo Castells (2005) se tornou interativo e compartilhado, mudando também suas interações sociais e organizacionais.

A mídia impressa e a comunicação eletrônica cada vez mais influenciavam o desenvolvimento e expansão das instituições modernas diretamente envolvidas com o imenso aumento na mediação da experiência que essas formas de mediação propiciaram (GIDDENS, 2002). Dupas (2001) aponta que a máquina é substituída pela informação e o contato entre as pessoas passa a ser mediado pela tela eletrônica.

É importante quando se observa as origens da alta modernidade, o desenvolvimento cada vez mais entrelaçado da mídia impressa e da comunicação eletrônica. A modernidade é inseparável de sua própria mídia, os textos impressos e, em seguida, o sinal eletrônico. Hoje a palavra impressa continua no centro da modernidade e das suas redes globais, e para Giddens (2002), praticamente todas as línguas conhecidas da humanidade foram impressas.

As imagens virtuais da televisão, do cinema e dos vídeos apresentam texturas de experiência via mídia que não estão disponíveis na palavra impressa. No entanto, como os jornais, as revistas e outros tipos de matéria impressa, esses meios são tanto a expressão das tendências globalizantes e desencaixadoras da modernidade, como instrumentos dessas tendências. Como modalidades de reorganização do tempo e do espaço, Giddens (2002) nota que as semelhanças entre os meios impressos e os eletrônicos são mais importantes que suas diferenças na constituição das instituições.

A tecnologia, na opinião de Dupas (2001), acabou se transformando em um dos componentes de poder, se prestando a ampliar a participação nos mercados globais para permitir novos investimentos em tecnologia e realimentar o ciclo de acumulação.

Castells (2005) que atribui grande peso a revolução das novas tecnologias de informação, ao apresentar as novas trajetórias organizacionais (produção flexível, novos métodos de gerenciamento, desenvolvimento de redes) ressalta que estas trajetórias não foram consequências automáticas da transformação tecnológica, pois a transformação da organização ocorreu como resposta à necessidade de lidar com um ambiente operacional em constante mudança. No entanto, uma vez iniciada, a transformação organizacional foi muito intensificada pelas novas tecnologias de informação.

A despeito das enormes vantagens dessas tecnologias há uma preocupação com o impacto social delas e muitos estudiosos observam que estas devem ser objeto de reflexão por parte da sociedade e do Estado. Dupas (2001) alerta que as tecnologias podem servir aos interesses da sociedade e ser um instrumento importante para o desenvolvimento da humanidade, ou podem servir ao interesse do capital e da acumulação e levar a efeitos danosos. Por outro lado, Castells (2005) chama atenção para o fato de que a tecnologia deve ser levada a sério. Precisa-se localizar o processo de transformação tecnológica revolucionária no contexto social em que ocorre e está sendo moldado, pois a habilidade ou 
inabilidade da sociedade e o Estado no seu domínio da tecnologia, especialmente em áreas estratégicas próprias de cada período histórico, influencia na capacidade de transformação das sociedades.

Apresentado o cenário político, econômico, social e tecnológico do mundo moderno, especialmente da modernidade tardia como Giddens a denomina, serão agora abordados os pontos principais da trajetória das universidades e das bibliotecas universitárias.

\section{AS UNIVERSIDADES NA MODERNIDADE}

Meneghel (2002) aponta que os conceitos de Razão e Estado nortearam o debate sobre a refundação da universidade após o esgotamento do modelo medieval. Hortale e Mora (2004) comentam que até o século XVIII, tinha-se uma universidade antiga, que vai da Idade Média, com pequenas alterações, até o final do século XVIII, quando as ideias do Iluminismo e da Revolução Francesa dão origem à universidade moderna.

Autores como Burke (2003) e Hortale e Mora (2004) acreditam que a inércia das universidades continuou até o início do século XIX, quando ainda desempenhavam sua função tradicional de ensino, não se constituindo, em geral, em lugares nos quais se desenvolviam ideias novas. A riqueza intelectual não era característica marcante nestas instituições.

Somente no início do século XIX houve uma grande mudança nas universidades com o nascimento do Estado-nação (idem, 2004). Para Magalhães (2004) o Estado-nação moderno assumiu financeiramente e legalmente as universidades e garantiu a estas a liberdade científica e pedagógica com a justificativa de que eram as bases do progresso, diferente da universidade medieval, que era de caráter independente, embora sob a proteção da Igreja, dos reis ou das cidades onde se estabeleciam. Argutamente, Hortale e Mora (2004) apontam que financeiramente, as universidades dependiam dos recursos das propriedades que as detinham ou do pagamento dos estudantes.

Assim, para Magalhães (2004) o Estado integrou o conjunto de instituições organizadas em um sistema que constitui a matriz moderna do ensino superior com a missão geral de servir a Nação e o Estado com a tarefa específica de produzir, preservar e difundir o conhecimento. O mesmo autor menciona, que o papel decisivo no projeto social, político e cultural das universidades deram-se não só por meio da consolidação dos Estados-nação, mas sob a metanarrativa da modernidade, concebidas como fábricas de conhecimento e como o local em que se criariam os funcionários que governariam a máquina estatal.

Neste sentido, as narrativas modernas em torno do Estado, mercado ou da comunidade, expressas pelas narrativas modernas de Hobbes, Locke, Adam Smith, Rousseau etc., encontram seus correspondentes nas narrativas das instituições de ensino superior de

\begin{tabular}{l|l|l|l|l|l} 
(C) RDBCI: Rev. Digit. Bibliotecon. Cienc. Inf. & Campinas, SP & v.15 & n.1 & p. 99-129 & jan./abr. 2017 \\
\hline
\end{tabular}


Humboldt, Jaspers e Newman, dentre outros, que possuem em comum sua fé no Homem, no conhecimento enquanto verdade e ciência e na História (idem, 2004).

Para lidar com os desafios da época, Ferreira (2009) aponta que passaram a ser referência para as demais instituições em diversos países, os três modelos ou tipologias diferentes para as universidades, que surgiram a partir da primeira metade do século XIX. O primeiro modelo, o francês nasceu em 1811, com a criação da Universidade Napoleônica, concebida como serviço estatal para promover o desenvolvimento econômico da sociedade, criando uma elite indispensável ao funcionamento do Estado. Entretanto, como apontam Hortale e Mora (2004), não havia autonomia universitária, já que os objetivos e programas eram os mesmos em todo o território nacional.

O segundo modelo surgiu na Alemanha, quando em 1808, Von Humboldt, instituiu na Universidade de Berlim, o modelo humboldtiano, que considerava a pesquisa o princípio básico da universidade. As universidades converteram-se em centros de desenvolvimento científico, controladas no seu funcionamento e financeiramente pelo Estado, mas com grande respeito à liberdade acadêmica (FERREIRA, 2009; HORTALE; MORA, 2004; MAGALHÃES, 2004).

O terceiro modelo foi o britânico de John Henry Newman, que fundou a Universidade de Dublin, em 1852, e escreveu o livro The Idea of the university, no qual defendia a universidade como aquela que entende que o conhecimento deve ser procurado como um fim em si mesmo, ensinando todos os ramos de conhecimento, enfatizando o desenvolvimento da personalidade dos estudantes por meio de uma concepção liberal da educação superior (FERREIRA, 2009; MAGALHÃES, 2004).

Para Magalhães (idem, 2004) a configuração moderna da universidade passou pela incorporação do conceito da razão, consolidação do Estado-nação, integração política das instituições no âmbito do Estado, consolidação deste como instância central de regulação, mas em articulação com o capitalismo.

$\mathrm{Na}$ primeira fase do capitalismo, no século XIX, denominado capitalismo liberal, Magalhães (ibidem, 2004), baseando-se em Boaventura de Sousa, mostra que o projeto da modernidade $^{3}$ é desequilibrado pelo capitalismo e surgem os excessos da regulação sobre a emancipação e uma hipertrofia do mercado em relação à comunidade e ao Estado. Na segunda fase, das últimas décadas do século XIX até 1960, denominada capitalismo organizado, o mercado apresentou uma expansão crescente e colocou-se ao lado do Estado na transformação que ocorreu em nível da comunidade e do Estado. Na sua terceira fase, finais

\footnotetext{
${ }^{3} \mathrm{O}$ projeto sociocultural da modernidade se baseia em dois pilares fundamentais, o pilar da regulação e o pilar da emancipação. O pilar da regulação é constituído pelo princípio do Estado, pelo princípio do mercado e pelo princípio da comunidade. O pilar da emancipação é constituído das três lógicas da racionalidade de Weber: racionalidade estético-expressiva da arte e da literatura, a racionalidade cognitivo-instrumental da ciência e técnica, a racionalidade moral prática da ética e do direito (SANTOS, 1995, p. 2 apud Magalhães, 2004, p. 39).

\begin{tabular}{l|l|}
$\mathrm{v} .15$ & $\mathrm{n} .1$
\end{tabular}

p. $99-129$

jan./abr. 2017
} 
dos anos de 1969 e início dos anos de 1970 até a atual fase, designada como capitalismo desorganizado, o mercado é cada vez mais aceito pelo Estado como regulador chave quer da vida econômica, quer da vida social.

Até a Segunda Guerra Mundial, a maioria das instituições de ensino superior em todo o mundo, era, basicamente, de elite, com críticas e pressões fortes contra o modelo elitista no final do segundo período do capitalismo organizado, que até então podia conviver com o capitalismo liberal, pois as universidades, segundo Magalhães (2004), não eram vistas como fator central de desenvolvimento socioeconômico.

Para Ferreira (2009), a partir da Segunda Guerra Mundial, a necessidade de massificar o ensino superior e de articular as atividades da universidade com as indústrias propiciou a criação do novo modelo para essas instituições com a transformação dos sistemas de ensino superior para o sistema de massas ${ }^{4}$ na segunda fase do capitalismo (capitalismo organizado últimas décadas do século XIX até 1960).

Nos anos de 1960, a expansão dos sistemas de ensino superior e as possibilidades do Estado-Previdência ${ }^{5}$ principalmente nos países de centro, atingiram seu ápice, e os sistemas de ensino superior começaram a ser concebidos como um fator econômico nacional, que produzia capital humano, afirmando-se a crença na importância da educação para o crescimento econômico de uma nação (MAGALHÃES, 2004; FERREIRA, 2009).

Para Magalhães (2004), a partir deste período, a justificativa mais comum e mais forte para o investimento político no ensino superior foi a importância econômica quando, em 1960, terminou a segunda fase do capitalismo organizado, o ensino superior sai de uma fase de grande segurança e identidade das instituições de ensino superior, onde havia consenso acerca do que era educação, de seus objetivos educacionais, sociais e políticos (Ibidem, 2004) para uma fase de grandes mudanças, entre 1960 e 1970, a do capitalismo desorganizado ${ }^{6}$ e que vem influenciando a educação superior como apresentamos a seguir.

\footnotetext{
${ }^{4}$ Magalhães (2004), usando a classificação de Trow (1973), definiu os três modelos de ensino superior como: a) de elite, aqueles que integram $15 \%$ da geração na faixa de idade de 18 a 24 anos; b) de massas, aqueles que integram 30 e $40 \%$; c) sistemas universais, aqueles que integram mais de $40 \%$ dessa população (MAGALHÃES, 2004, p. 72-77).

${ }^{5}$ Estado-Previdência, do bem-estar social, do Welfare State, é um tipo de organização política e econômica que coloca o Estado (nação) como agente da promoção (protetor e defensor) social e organizador da economia. Cabe ao Estado de bem-estar social garantir serviços públicos e proteção à população (Wikipédia, a enciclopédia livre. Disponível em: http://pt.wikipedia.org/wiki/Estado_de_bem-estar_social. Acesso em: 6 de jun. 2010). O Estado-Previdência, para Rosanvallon (1997, p. 20-23), deve ser compreendido como um aprofundamento do Estado-protetor clássico que nasceu como Estado moderno.

${ }^{6}$ A designação de capitalismo desorganizado só pode ser aceita como característica do modo de regulação emergente na medida em que o círculo vicioso fordista está sendo desmantelado e o desmantelamento das forças organizacionais é muito mais visível do que o perfil das formas que as irão substituir. No que se refere à emergência dos pós-fordismo como modo de regulação, ele está sendo introduzido, simultaneamente, como contexto e instância de regulação. Neste sentido, pode ser enganadora a designação de capitalismo desorganizado para identificar o período em questão, pois o capitalismo parece nunca antes ter estado tão organizado e dominante (BECK, 1997 apud MAGALHÃES, 2004, p. 88; SANTOS, 1995, p. 82 apud MAGALHÃES, 2004).
} 
A partir da década de 1970 houve uma queda na produtividade econômica e isso contribuiu para a estagnação e crescimento da despesa pública em educação nos países desenvolvidos, principalmente na educação superior, além de fatores como a massificação do ensino e o desemprego dos graduados (CONCEIÇÃO et al., 1998 apud FERREIRA, 2009).

Há uma degradação dos processos de regulação ligados à crise do Estado-Previdência, desde o início dos anos de 1970, no capitalismo desorganizado. As formas organizacionais fordistas foram sendo substituídas por outras. Magalhães (2004) relembra que no capitalismo organizado a lógica do mercado era equilibrada por uma intervenção estatal relativamente forte; no capitalismo desorganizado o mercado é cada vez mais aceito pelo Estado como regulador chave.

Os mercados tornaram-se globais, a produção tornou-se globalizada, a distribuição tornou-se mais fácil e menos dispendiosa pelo uso de novas tecnologias de comunicação e desenvolvimento de meios de transporte, permitindo que a circulação de produtos dos recursos humanos, do conhecimento e da informação, se faça com uma rapidez sem precedentes (Idem, 2004).

Em 1980, o cenário dos sistemas de ensino superior é pós-fordista, de desagregação e substituição do Estado no âmbito do capitalismo e no declínio do Estado-Previdência, que é acusado de ineficiência. $\mathrm{O}$ círculo fordista que foi reconfigurado na combinação entre a regulação e intervenção pelo Estado tinha uma dinâmica e um âmbito nacional por meio do Estado; já o círculo do pós-fordismo parece ser feito na base da desregulação do mercado e do próprio Estado e parece ter uma dinâmica e um âmbito globais (Ibidem, 2004).

Apesar deste contexto de desintegração-desagregação-substituição, os Estado-Nação ainda são instâncias muito fortes de regulação social, econômica e política. Há uma aparente combinação da desregulação e da regulação estatal ${ }^{7}$, pois os governos ainda regulam, embora

\footnotetext{
${ }^{7}$ Em uma análise detalhada dos significados do termo "regulação", Barroso (2005) afirma que hoje se assiste a uma transformação profunda no modo como é entendida e posta em prática a regulação das políticas educativas no contexto da concepção, reforma e reestruturação do Estado. O Estado é uma fonte essencial de regulação, mas não é a única e, por isto, não se pode dizer que se vive num período de desregulação do sistema educativo, o que seria ignorar as múltiplas fontes de regulação a que o sistema está sujeito (por parte dos professores, pais, comunicação social e outros agentes).

As diversidades de fontes e modos de regulação fazem com que a coordenação, equilíbrio ou transformação do funcionamento do sistema educativo resulte mais na interação dos vários dispositivos reguladores do que na aplicação linear de regras e orientações oriundas do poder político, e por isto melhor seria falar em multirregulação (BARROSO, 2005, p. 732-734).

Estudos realizados nos países da Europa identificaram características de um modo de regulação comum: oposição ao modelo burocrático profissional (baseado na aliança entre Estado e professores, combinando uma regulação estatal, burocrática e administrativa com uma regulação profissional, corporativa e pedagógica) e convergência a modelos de governança e desregulação que se designam como pós-burocráticos e organizamse em torno de dois referenciais principais: o do Estado avaliador e o do quase mercado. Contudo, essas convergências são parciais por que as políticas de cada país se referem a estes modelos em proporções diferentes e estas políticas se desenvolvem a partir de contextos de partida diferentes (BARROSO, 2005, p. 735-737).

\begin{tabular}{|c|c|c|c|c|c|}
\hline (C) RDBCI: Rev. Digit. Bibliotecon. Cienc. Inf. & Campinas, SP & V.15 & n. & p. 99-129 & jan/abr. 2017 \\
\hline
\end{tabular}
}


em seus discursos ainda afirmarem que estão deixando a regulação a cargo das leis do mercado (Ibidem, 2004, p. 99).

Continuando, Magalhães (2004) comenta que o mercado parece ocupar o centro político no que diz respeito à regulação em dois níveis diferentes: num primeiro nível, surge com o ambiente sem o qual os sistemas sociais não sobreviveriam; num segundo nível, surge como dispositivo retórico para legitimação de determinadas políticas. A mudança de natureza da regulação estatal afeta naturalmente a relação entre os governos e o ensino superior.

Atualmente, como mostrado acima, há o surgimento de um novo modelo de regulação estatal e uma nova fundação narrativa baseada no empreendedorismo ou empresarialismo. Essa forma de regulação emergente é híbrida como se houvesse uma combinação de elementos de regulação estatal e elementos de autorregulação (Ibidem, 2004).

A narrativa de hoje induz a uma diversidade de discursos sobre o ensino superior, mas, também, a um discurso que assume a posição central, que é a narrativa empreendedora/empresarialista e a do mercado, com a justificativa de que o empresarialismo é a melhor maneira de lidar com o ensino superior de massa. Esta narrativa empresarialista está sendo assumida até mesmo em países aonde o ensino superior de massas ainda não chegou (Ibidem, 2004).

As críticas ao sistema universitário são muitas e as discussões no âmbito do Acordo Geral sobre o Comércio de Serviços (AGCS) e da Organização Mundial do Comércio (OMC), na década de 1990, olham a educação como um bem ou serviço de natureza comercial. As universidades europeias, de acordo com Sánchez (2003 apud FERREIRA, 2009), são obsoletas e passam a ser vistas como causa importante da perda de competitividade para atrair alunos e prestar serviços internacionais.

Dentro dessa perspectiva de competitividade, de prestador de serviço econômico, vêm sendo exigidos das universidades novos papéis sociais para atender à nova necessidade da Europa frente à disputa pela hegemonia global (FERREIRA, 2009).

Nesta nova relação que está emergindo entre as instituições de ensino superior e o Estado, surgem instrumentos de autonomia, prestação de contas e avaliação de qualidade, cujo modelo, pelo menos na sua formulação política, já é evidente na Europa Ocidental, Austrália e mesmo em países em desenvolvimento, como o Brasil (MAGALHÃES, 2004).

Na ótica de Ferreira (2009) as reformas surgem e os sistemas de educação superior, entre 1980 a 2000, sofrem em vários países modificação significativa nas políticas de financiamento, qualidade, avaliação, prestação de contas e gestão das IES. Exemplos disto são as mudanças que estão acontecendo na Europa, tendo como base o Processo de Bolonha, e as que também estão ocorrendo no Brasil, especialmente a partir de 1990. 
Há duas décadas, os modelos de universidades europeias são revistos pelos países, culminando com o Processo de Bolonha que, na visão de Hortale e Mora (2004), é, possivelmente, a maior transformação na história das universidades europeias desde o princípio do século XIX.

O Processo de Bolonha é uma meta-política pública, de um meta-Estado, iniciado em 1999, de construção de um espaço de educação superior na Europa até o ano de 2010, cujo objetivo essencial é o ganho de competitividade do Sistema Europeu de Ensino Superior frente a países e blocos econômicos. Para Lima; Azevedo; Catani (2008), esse projeto paneuropeu visa harmonizar os sistemas universitários nacionais, de modo a equiparar graus, diplomas, títulos universitários, currículos acadêmicos e adotar programas de formação contínua reconhecíveis por todos os Estados membros da União Europeia.

Neste cenário de mudanças em que a narrativa moderna, o Estado, o capitalismo e o mercado se articulam com a educação superior, as novas tecnologias no contexto da educação superior, principalmente, a partir de 1990, vêm trazendo mudanças, embora não se tenha a real dimensão da extensão e dos benefícios dela.

As novas tecnologias de informação, em uma análise mais recente de Santos (2008), se constituem em um dos fatores decisivos - além da transformação política e do tipo de conhecimento produzido na universidade - para o abalo da universidade, nesta última década no âmbito do desenvolvimento do projeto neoliberal de transnacionalização do mercado da educação superior.

Tendo este cenário moderno como palco do contexto político, econômico, social e tecnológico que dominou o mundo moderno e as universidades, a seguir, será analisada a trajetória das bibliotecas universitárias do século XVII até início do século XXI.

Vale a pena mencionar aqui que, apesar de extenso levantamento no Portal da CAPES, Google Acadêmico, no catálogo da Biblioteca da UnB, na Base de Dados de Teses e Dissertações do IBICT, usando os termos bibliotecas universitárias, história bibliotecas universitárias (bem como os termos estrangeiros: bibliothèques universitaires, academics libraries, university library), no cenário mundial foram localizados poucos documentos sobre a história em nível macro das bibliotecas universitárias.

\section{AS BIBLIOTECAS UNIVERSITÁRIAS NOS TEMPOS MODERNOS}

No contexto das mudanças dentro do sistema acadêmico, entre o Renascimento e o Iluminismo, em que as tendências passavam pela redefinição do conhecimento à reformulação das instituições, para Burke (2003) houve nas bibliotecas universitárias uma reclassificação de seu material, parte do resultado de mudanças na organização das universidades, mas também resultado da multiplicação de livros que se seguiu à invenção da imprensa. 
$\mathrm{Na}$ Europa, as melhores bibliotecas no período do século XVI ao XVIII, na Itália e na França, encontravam-se nas maiores cidades, como Florença (com a Laurenziana), Veneza (com a Marciana), Milão (com a Ambrosiana), e, acima de todas, Roma, com o Vaticano, a biblioteca da Universidade da Sapienza, a biblioteca jesuíta no Colégio Romano e a Angélica, que abriu em 1614, além das bibliotecas privadas (Ibidem, 2003).

De acordo com Dain (1990 apud WEINER, 2005), nos Estados Unidos, antes do século XIX, as bibliotecas, com exceção de Harvard e Yale, eram medíocres e desertas como as suas faculdades.

Nos séculos XVII e XVIII, época em que pesquisadores em matemática e em filosofia das ciências estavam voltados para o futuro, houve mudanças na atividade dos bibliotecários e na organização das bibliotecas, bem como na maneira de ler os livros. Para Mckitterick (2006) dessas mudanças provocaram a transformação da bibliografia, que se manifestou nas bibliotecas de eruditos como Gesner (Pandectae, 1548) ou de Possevinus (Bibliotheca Seleta, 1593), tendo-se aí o fundamento dos sistemas bibliográficos e de suas classificações.

Burke (2003) ao analisar como a classificação do conhecimento acadêmico entrava na prática cotidiana das universidades europeias, observou, principalmente nos séculos XV a XVIII, que a disposição dos livros nas bibliotecas das universidades se caracterizava como um reforço da segunda perna do tripé intelectual (composto de currículo, biblioteca e enciclopédia), no sistema tradicional de disciplinas. Para esse autor (idem, p. 88-89), a ordem dos livros reproduzia o currículo da universidade e sustentava esse sistema de classificação, como ainda a universidade faz, tornando-o material físico e espacial. As bibliotecas que sobreviveram permitem o estudo da 'arqueologia do conhecimento' como Foucault dizia, examinando os vestígios físicos de antigos sistemas de classificação. A enciclopédia, terceira perna do tripé, cujo termo é traduzido do grego como o "círculo do aprendizado", (aspas do autor) originalmente se referia ao currículo educacional.

A despeito dos problemas práticos da biblioteconomia que aparecem na classificação, esta constitui ainda hoje, de acordo com Mckitterick (2006), numa espécie de controle dos meios de ler para descobrir o que o usuário procura de informação e, quer seus fundamentos seja filosófico, teológico, ou simplesmente prático, a classificação, continua sendo um procedimento destinado a aproximar os leitores dos escritores.

Continuando o autor (Ibidem, 2006) aponta que hoje, com a chegada da memória eletrônica põem em questão as subdivisões, quer seja manuscrito, impresso, textos datilografados, fotocópias e se pode perceber um retorno a um conceito de leitura, que não se vê desde o século XVI: uma biblioteca na qual os manuscritos e impressos, as pinturas e gravuras, escultura, dentre outros, participem no mesmo plano de classificação e da complexidade dos conhecimentos humanos. 
Para Burke o acesso dos usuários às primeiras bibliotecas modernas dependia das atitudes dos bibliotecários e da sua equipe. Um viajante inglês do século XVII, Richard Lassels, observou com satisfação que a Ambrosiana "abre suas portas a todos os que vêm e vão e permite que leiam todo livro que desejem" e que em Roma, a biblioteca da universidade e a dos agostinianos era "abertas todos os dias, com um cavalheiro cortês para lhe entregar qualquer livro solicitado" (BURKE, 2003, p. 160).

Até o século XVIII, de acordo com Boden (1993), não havia um padrão de classificação nas bibliotecas americanas, mas no século de XIX, a partir de 1876, foi adotado o sistema de Classificação Decimal Dewey e, neste mesmo ano, foi criada a American Library Association que contribuiu para a padronização e cooperação entre as bibliotecas.

Nos séculos XIX e início do século XX, as bibliotecas americanas desenvolveram uma estrutura formal e se tornaram parte integrante da missão da universidade servindo a professores e alunos, apoiando os currículos e pesquisas (WEINER, 2005).

No início do século XX, foi substituída a ênfase que as bibliotecas universitárias americanas davam à preservação e ao abrigo das coleções por acesso e uso para fazê-las acessíveis; houve reconhecimento da necessidade de oferecer um serviço eficiente e personalizado ao usuário e foi reconhecido o uso da classificação por assunto e não por sua localização fixa, na prateleira. Para autores como Hamlin (199---?), Dain (1990) e Wiegand (1996, apud WEINER, 2005), a cooperação entre bibliotecas começou a ser considerada como vantajosa e o financiamento da biblioteca começou a ser responsabilidade da instituição à qual a biblioteca estava vinculada.

No pós-guerra, com a ênfase da universidade no ensino dos conteúdos fatuais e conceituais, na dependência do aluno em relação ao docente, tendo como consequência um aprendizado programado, orientado pelas disciplinas, as bibliotecas universitárias tornam-se recursos importantes para atividades de ensino, pesquisa e extensão (LUZ, 1989, apud DUDZIAK, 2008; WEINER, 2005; DUDZIAK, 2008).

Durante a década de 1960, os desenvolvimentos da computação e das telecomunicações revolucionaram os serviços das bibliotecas universitárias. A primeira aplicação básica da tecnologia foi a aceitação ampla da máquina de fotocópia, especialmente para empréstimo interbibliotecário de artigos de periódicos, ao invés do envio do próprio periódico (DUPUY, 1968; HAMLIN, 1981 apud BODEN, 1993).

Para Lee (1989 apud BODEN, 1993) os serviços de indexação e resumos iniciaram o uso de composição fotográfica e impressão de seus produtos. Isto significaria que depois a informação poderia ser usada em bases de dados legível por máquina. Esta é uma das razões de bases de dados como a Education Resources Information Center (ERIC) estarem disponíveis em linha ou em compactos discos, a partir dos anos de 1960. 
Nos Estados Unidos a primeira rede de bibliotecas foi iniciada em 1961 com a National Library of Medicine Medical Literature and Retrieval System (MEDLARS). O principal desenvolvimento dos anos de 1960 foi a criação e implantação do formato Machine Readable Cataloging (MARC) pela Library of Congress. Para BODEN (1993) este conjunto de padrão de catalogação foi instrumento de sucesso em redes de catalogação cooperativa.

Com o propósito de desenvolver um sistema informatizado que permitisse as universidades do Estado de Ohio compartilhar recursos e reduzir gastos, a Ohio College Library Center, fundada em 1967, iniciou, nesse mesmo ano, um serviço de catalogação cooperativa com 54 bibliotecas de Ohio. Até 2005, o banco de dados integrava dados de coleção de quase todas as bibliotecas do país e algumas internacionais (BODEN, 1993, p. 13; OCLC apud WEINER, 2005). Nos anos seguintes o OCLC expandiu-se, notadamente com o sucesso do seu Worldcat, um catálogo coletivo que engloba acervos de milhares de bibliotecas de mais de cem países.

As transformações tecnológicas na década de 1970, segundo Weiner (2005), causaram grandes mudanças na disponibilidade e uso dos recursos eletrônicos e aumento das pressões econômicas sobre os gestores das bibliotecas universitárias levaram ao questionamento do papel da biblioteca tradicional.

Na década de 1980, o aumento de preços de periódicos científicos favoreceu ao modelo de acesso à coleção informacional, ao invés de sua compra, apoiado em recursos eletrônicos (MILLER apud WEINER, 2005).

Nas décadas de 1980 e 1990, de acordo com Dudziak (2008), as tecnologias de informação e comunicação e a necessidade de garantir a eficiência e qualidade exigiram a implantação da lógica sistêmica que levaram as bibliotecas universitárias a mudanças significativas. Foi adotada nas bibliotecas universitárias uma nova lógica de serviço e de fluxos de informação e comunicação entre estas organizações, com padrões e serviços sistêmicos, o que aproximou bibliotecas e bibliotecários, antes distantes. A ênfase dada ao acervo passou ao acesso à informação, utilizando-se cada vez mais dos sistemas de tecnologia de informação e comunicação.

\section{Para a Dudziak (2008, p. 4)}

com base no desenvolvimento de serviços de acesso à informação e treinamento dos usuários a biblioteca universitária, se desenvolveu. Surgiram os consórcios de bibliotecas, dividindo responsabilidades, [...] que, [...] permitiram maior rapidez no atendimento, consequente redução de custos e melhor aproveitamento de pessoas.

Segundo Cunha (2000) a biblioteca que, através dos séculos, foi para a universidade o ponto central, com o seu acervo de obras impressas, preservando o conhecimento da civilização, atualmente seu acervo existe sob muitas formas: texto, gráfico, som, algoritmo e simulação da realidade virtual, distribuído em redes mundiais, em representações digitais, acessíveis a qualquer indivíduo e não somente os acadêmicos.

\begin{tabular}{l|l|l|l|l|l} 
(C) RDBCI: Rev. Digit. Bibliotecon. Cienc. Inf. & Campinas, SP & v.15 & n.1 & p. 99-129 & jan./abr. 2017 \\
\hline
\end{tabular}


As bibliotecas universitárias, neste século XXI, na visão de Dudziak (2008), seguem a tendência de hibridização das instituições e vão se constituindo como um conjunto de recursos, realizando uma gama de atividades educativas e informativas. Tornam-se parte essencial do ambiente universitário, passando a interagir constantemente com outros sistemas.

\section{CONSIDERAÇõES FINAIS}

Como visto anteriormente e embasado em Abrantes (1998), Magalhães (2004) e Soares (2001), a partir do final do século XVI e início do século XVII, as sociedades na modernidade centram sua organização em torno da razão e a ciência triunfa, com o seu método de investigação racional e experimental, e vai se afirmando uma forte tendência a uma imagem mecânica da natureza na construção de teorias científicas.

A partir do século XIX, há um período de progresso quase ininterrupto na melhoria das condições de vida. O Estado e a sociedade se pautam pelos valores da razão, do debate público, da educação, da ciência. Os conhecimentos científicos são desenvolvidos para criar novas indústrias, as relações entre ciência, tecnologia e economia tornam-se visíveis, e já se pode observar transformações de cunho teórico e político no ensino superior. Coincidindo, no século XIX a forma de organização e desenvolvimento econômico social, o capitalismo, que está em sua fase do capitalismo liberal, se articula com a matriz moderna do ensino superior. Para Hobsbawm (1995), Japiassú (2001), Szmrecsányi (2001) e Magalhães (2004), o saber científico é considerado como um sistema formado e coerente de conhecimento e as atividades de pesquisa começam a se sistematizar.

O Estado-nação, nas opiniões de Weber (1999) e de Giddens (2002), se constitui em uma das formas sociais mais importantes produzidas pela modernidade, criando maiores oportunidades para capitalismo moderno ocidental.

No século XIX, as universidades surgem como modernas, a educação é assumida pelo Estado e isto significa uma grande mudança nas universidades, pois o Estado oferece uma cobertura legal que garante às universidades a liberdade científica e pedagógica sob a justificativa de que estas eram a base do progresso. Configuram-se modelos para ensino superior/universidades inspirados nas narrativas modernas que marcam o advento da universidade moderna como agente de reconstrução nacional conforme apontados por Hortale e Mora (2004); Magalhães (2004) e Ferreira (2009).

Para Magalhães (2004) e Ferreira (2009), nos decênios de 1960 e 1970, as IES gradativamente iniciam sua transformação para o ensino de massas e os sistemas de ensino superior começam a ser concebidos como um fator econômico nacional. Há mudanças na linha de evolução do capitalismo, aparece a grande revolução tecnológica e o mundo entra em crise, segundo Hobsbawm (1995) e Castells (2005). 
A revolução tecnológica que ocorreu depois de 1973 foi decisiva no aumento para desenvolvimento econômico e produziu grandes transformações na vida cotidiana e na forma de trabalho. O mundo capitalista sofreu profundas transformações depois de 1980, como a formação do Estado mínimo e de mercados emergentes em substituição ao projeto nacional e em direção ao projeto do capitalismo transnacional (HOBSBAWM, 1995; IANNI, 1999; CASTELLS, 2005).

As IES, que conviviam, segundo Magalhães (2004), desde as últimas décadas do século XIX com a lógica do capitalismo organizado em uma dinâmica de âmbito nacional, por meio do Estado, no período entre 1960 e 1970, entram numa fase de grandes mudanças, que parece ter uma dinâmica e um âmbito globais.

O Estado se transforma na sua natureza de regulação e essa transformação afeta a relação entre os governos e o ensino superior. O mercado é cada vez mais aceito pelo Estado como regulador na vida econômica e na vida social; na década de 1990 a educação, para Magalhães (2004) e Ferreira (2009) é considerada como um bem de natureza comercial.

Na nova relação que está emergindo entre as instituições de educação superior e o Estado, os sistemas de educação superior sofrem, em vários países, modificações nas políticas de financiamento, qualidade, avaliação, prestação de contas e gestão das IES e as universidades se defrontam com crises como a da produção do conhecimento, a falta de um consenso sobre as suas funções, a pressão do mercado e do Estado para submetê-las a critérios de produtividade (MAGALHÃES, 2004; SANTOS, 2008; FERREIRA, 2009).

A biblioteca universitária, inserida neste contexto, teve seu desenvolvimento tecido ao longo dos séculos, tentando acompanhar as mudanças no sistema acadêmico, quer adequando seu acervo às mudanças das IES, quer utilizando tipos diversos de classificação bibliográfica, quer atendendo a usuários, embora sem o amplo acesso, quer tendo como referência principal de seu papel a preservação do conhecimento por meio do acervo que mantinha.

Mas é no decorrer do século XIX que alguns padrões de serviços e o entendimento da relação da biblioteca universitária foram surgindo. É neste período em que o Estado se articula com o capitalismo liberal e as universidades modernas são vistas como a base para o progresso. As propostas de modelos transitam apontando para seu papel na formação de funcionários para o Estado, ou formação de pesquisadores, ou formação da personalidade dos estudantes, as bibliotecas universitárias vão sendo lentamente estruturadas.

Para Boden (1993), Weiner (2005) e Mckitterick (2006), as bibliotecas universitárias que, em geral, até início do século XIX, mantiveram sua função tradicional de preservação sem grandes mudanças na área de serviços técnicos, puderam contar no final do século com um padrão de classificação. 
Entretanto, foi no decorrer do século XX, a partir da Segunda Guerra até, aproximadamente, 1970, que no capitalismo organizado, o ensino começa sua caminhada para o ensino de massa, que a biblioteca universitária se torna uma parte importante na universidade para contribuir com seus objetivos de ensino, pesquisa e extensão. Cresce a ênfase ao acesso das coleções, há financiamento do Estado para desenvolvimento de coleções e estruturação de suas bibliotecas, dão-se início as atividades de cooperação, e as atividades de automação começam a transformar a forma como são oferecidos os serviços e produtos das bibliotecas universitárias (MAGALHÃES, 2004; WEINER, 2005; DUDZIAK, 2008; FERREIRA, 2009).

A partir de 1970, outro cenário se desenha. Com decréscimo nas atividades econômicas, o capitalismo entra em uma fase em que o mercado é cada vez mais aceito pelo Estado como regulador e os sistemas de ensino superior são regulados cada vez mais pelo mercado com o aceite do Estado, que agora veem a educação superior como um serviço econômico. As novas tecnologias penetram nessas áreas com a rapidez e interatividade que lhe são características e propiciam juntamente com dinâmica do círculo pós-fordista uma dinâmica globalizada. As universidades e suas bibliotecas são afetadas em função de mudanças neste cenário e propostas de reformas surgem lideradas pelo processo de Bolonha gerando novos desafios para estas duas instituições centenárias. 


\section{DESARROLLO DE LAS UNIVERSIDADES Y BIBLIOTECAS UNIVERSITARIAS EN LA EDAD MEDIA A LA MODERNIDAD}

RESUMEN: El ensayo analiza el origen de las universidades, sus luchas por la autonomía, la organización de las estructuras administrativas y curriculares e informa de la existencia de bibliotecas vinculadas a las universidades, desde la Edad Media a la Modernidad. En el siglo XIX la educación es asumida por el Estado, la creación de una cobertura legal que ofrece a las universidades la libertad científica y pedagógica. La biblioteca de la universidad tuvo su desarrollo a lo largo de los siglos, tratando de mantenerse al día con estos cambios. Pero es durante este siglo que han surgido algunos servicios y la relación de la biblioteca de entendimiento con la universidad. Sin embargo, fue a partir de la Segunda Guerra Mundial que la enseñanza comienza a ser característico de actividad de masas, y la biblioteca de la universidad se convierte en una parte importante de la institución. Hay un creciente énfasis en el acceso a las colecciones, no hay financiación estatal para el desarrollo de colecciones y estructuración de sus bibliotecas, dan temprano para actividades de cooperación y de automatización. Estos comienzan a cambiar la forma en que se ofrecen los servicios y productos de las bibliotecas universitarias. A partir de 1970, las nuevas tecnologías penetran en estas áreas, y las universidades y sus bibliotecas se ven afectados por este tipo de tecnologías. Las propuestas de reforma surgen generando nuevos retos para estas dos instituciones centenarias.

PALABRAS CLAVE: Biblioteca universitaria. Edad Media. Modernidad.

Submetido em: 31/05/2016

Aceito em: 05/12/2016

Publicado em: 19/12/2016

\section{REFERÊNCIAS}

ABRANTES, Paulo César Coelho. Imagens da natureza, imagens de ciência. São Paulo: Papirus, 1998.

ANDERY, Maria Amália et al. Para compreender a ciência: uma perspectiva histórica. 11. ed. São Paulo: EDUC, 2002.

AZEVEDO, Janete M. Lins de. A educação como política pública. São Paulo: Autores Associados, 2004.

BARROSO, J. O Estado, a educação e a regulação das políticas públicas. Educação e Sociedade, Campinas, v. 26, n. 92, p. 725-751, 2005. Disponível em:

<www.scielo.br/pdf/es/v26n2/v26n2a02.pdf > Acesso em: 27 nov. 2012.

BOBBIO, N. Estado, governo e sociedade: para uma teoria geral da política. São Paulo: Paz e Terra, 1987.

BODEN, Dana W. R. A history of the utilization of technology in academic libraries. Educational Research Information Center (ERIC), Washington, DC, 1993. Disponível em: <http://www.eric.ed.gov/PDFS/ED373806.pdf>. Acesso em: 13 maio 2012. 
BURKE, Peter. Uma história social do conhecimento: de Gutenberg a Diderot. Rio de Janeiro: Zahar, 2003.

CASTELLS, Manuel. A sociedade em rede: a era da informação: economia, sociedade e cultura. Rio de Janeiro: Paz e Terra, 2005. v. 1.

CUNHA, Murilo Bastos da. Construindo o futuro: a biblioteca universitária brasileira do ano 2000. Ciência da Informação, Brasília, v. 29, n. 1, p. 71-89, jan. /abr. 2000. Disponível em: <http://www.scielo.br/pdf/ci/v29n1/v29n1a8.pdf >. Acesso em: 2 dez. 2011.

DUDZIAK, E. A. Ecossistemas bibliotecários: novos paradigmas das bibliotecas universitárias e sua relação com a inovação educativa numa sociedade do conhecimento. In: SEMINÁRIO NACIONAL DE BIBLIOTECAS UNIVERSITÁRIAS (SNBU), 15., 2008, São Paulo, SP. Anais eletrônicos. São Paulo: CRUESP, 2008. p. 1-11. Disponível em: <http://eprints.rclis.org/bitstream/10760/12672/1/SNBU_2008.pdf >. Acesso em: 4 dez. 2011.

DUPAS, Gilberto. Ética e poder na sociedade da informação: de como a autonomia das novas tecnologias obriga a rever o mito progresso. São Paulo: UNESP, 2001.

ELIAS, Norbert. O processo civilizador: a formação do Estado e civilização. Rio de Janeiro: Zahar, 1993. v. 2.

ESCOLAR SOBRIÑO, Hipólito. História de las bibliotecas. 3. ed. Madrid: Fundación Geman Sanches Ruipérez, 1990.

FERREIRA, Suely. A universidade do século XXI: concepções finalidades e contradições. 2009. 305 f. Tese (Doutorado da Universidade Federal de Goiás, Goiânia, 2009). Disponível em: <http://bdtd.ufg.br/tedesimplificado/tde_busca/arquivo.php?codArquivo=751>. Acesso em: 16 mar. 2011.

GIDDENS, Anthony. As consequências da modernidade. São Paulo: UNESP, 1991.

GIDDENS, Anthony. Modernidade e identidade. Rio de Janeiro: Zahar, 2002.

GOODY, Jack. O roubo da história: como os europeus se apropriam das ideias e invenções do Oriente. Tradução de Luiz Sergio Duarte da Silva. São Paulo: Contexto, 2008.

HARVEY, David. Condição pós-moderna. 14. ed. São Paulo: Loyola, 1989.

HOBSBAWM, Eric. Era dos extremos: o breve século XX, 1914-1991. São Paulo: Companhia das Letras, 1995.

HORTALE, Virginia Alonso; MORA, José-Ginés. Tendência das reformas da educação superior na Europa no contexto do processo de Bolonha. Educação e Sociedade, Campinas, v. 25, n. 88, p. 937-960, out. 2004. Disponível em:

<http://www.scielo.br/pdf/\%0D/es/v25n88/a14v2588.pdf > . Acesso em: 20 abr. 2011.

IANNI, Octavio. O Estado-Nação na época da globalização. Econômica: Revista da PósGraduação em Economia da Universidade Federal Fluminense, Niterói, v. 1, n. 1, p. 105-118,

\begin{tabular}{l|l|l|l|l|l} 
(C) RDBCI: Rev. Digit. Bibliotecon. Cienc. Inf. & Campinas, SP & v.15 & n.1 & p. 99-129 & jan./abr. 2017 \\
\hline
\end{tabular}


jun. 1999. Disponível em: <http://boletimef.org/biblioteca/576/O-Estado-Nacao-na-epoca-daglobalizacao>. Acesso em: 15 de nov. 2011.

JAPIASSÚ, Hilton. O projeto masculino-machista da ciência moderna. In: SOARES, Luiz Carlos (Org.). Da revolução científica à big (Business) science. São Paulo: HUCITEC, 2001. p. 67-104.

LE GOFF, Jacques. Os intelectuais da Idade Média. 6. ed. São Paulo: Brasiliense, 1995.

LYOTARD, J.F. A condição pós-moderna. Lisboa: Gradiva, 1985.

LIMA, L. C.; AZEVEDO, M. L. N.; CATANI, A. M. O processo de Bolonha, a avaliação da educação superior e algumas considerações sobre a Universidade Nova. Avaliação, Campinas, v. 13, n. 1, mar. 2008. Disponível em: <http://www.scielo.br/pdf/aval/ v13n1/a02v13n1.pdf>. Acesso em: 13 set. 2009.

MAGALHÃES, António M. A identidade do ensino superior: política, conhecimento e educação, numa época de transição. Porto: Fundação Calouste Gulbenkian, 2004. (Série Textos Universitários de Ciências Sociais e Humanas).

MCKITTERICK, David. A biblioteca como interação: a leitura e linguagem da bibliografia. In: BARATIN, Marc; JACOB, Christian (Org.). O poder das bibliotecas: a memória dos livros no Ocidente. Rio de Janeiro: UFRJ, 2006. p. 94-107.

MENEGHEL, Stela Maria. A crise da universidade moderna no Brasil. In: REUNIÃO ANUAL DA ANPED, 25., 29 set. 2002, Caxambu, MG. Anais eletrônicos. Caxambu, 2002. Disponível em: <http://www.anped.org.br/reunioes/25/stelamariameneghelt11.rtf $>$. Acesso em: 18 mar. 2010.

MENEGHEL, Stela Maria. Políticas de modernização da universidade no Brasil: a reforma universitária de 1968 e a LDB/96. E-GOV Portal de e-governo, inclusão digital e sociedade do conhecimento. Brasília, 2002. Disponível em: <http://www.buscalegis.ufsc.br/revistas/files/anexos/29119-29137-1-PB.pdf >. Acesso em: 18 out. 2011.

NOBRE, Renarde Freire. Weber e o racionalismo ocidental. In: CARVALHO, Alonso Bezerra; BRANDÃ O, Carlos da Fonseca. Introdução à sociologia da cultura: Max Weber e Norbert Elias. São Paulo: Avercamp, 2005.

OLLÈ, James G. Library history: an examination guidebook. London: Clive Bingley, 1971.

OPUSZKA, Paulo Ricardo. Racionalização, Civilização e história social do conhecimento: Diálogos entre Weber, Elias e Peter Burke para uma Aproximação de discursos sobre Intervenção Social. Cadernos da Escola de Direito e Relações Internacionais, Curitiba, v. 14, v. 1, p. 317-334, 2011. Disponível em:

<http://Apps.Unibrasil.Com.Br/Revista/Index.Php/Direito/Article/Viewfile/458/379>. Acesso em: 31 nov. 2011.

SANTOS, Boaventura de Sousa. A universidade no séc. XXI: para uma reforma democrática e emancipatória da universidade nova. In: SANTOS, Boaventura de Sousa; ALMEIDA

\begin{tabular}{|c|c|c|c|c|c|}
\hline (C) RDBCI: Rev. Digit. Bibliotecon. Cienc. Inf. & Campinas, SP & V.15 & n. 1 & p. 99-129 & ian/abr 2017 \\
\hline
\end{tabular}


FILHO, Naomar de. A universidade no séc. XXI: para uma universidade nova. Coimbra, Portugal: Almedina, 2008.

SOARES, Luiz Carlos. O nascimento da ciência moderna: os caminhos diversos da revolução científica nos séculos XVI e XVII. In: SOARES, Luiz Carlos (Org.). Da revolução cientifica à big (business) science. São Paulo: HUCITEC, 2001. p. 17-66.

SZMRECSÁNYI, Tamás. Espaços de história econômica da ciência e da tecnologia. In: SOARES, Luiz Carlos (Org.). Da revolução cientifica à big (business) science. São Paulo: HUCITEC, 2001. p. 155- 200.

VERGER, Jacques. Homens e saber na Idade Média. São Paulo: EDUSC, 1999.

WEBER, Max. Economia e sociedade: fundamentos da sociologia compreensiva. Brasília, DF: Universidade de Brasília, 1994-1999. 2 v.

WEINER, Sharon Gray. The History of academic libraries in the United States: a review of the literature. Library Philosophy and Practice, Lincoln, NE, v. 7, n. 2, 2005. Disponível em: 〈http://www.webpages.uidaho.edu/ mbolin/weiner.htm>. Acesso em: 15 set. 2011.

Wikipédia, a enciclopédia livre. Disponível em: http://pt.wikipedia.org/wiki/Estado_de_bemestar_social. Acesso em: 6 de jun. 2011.

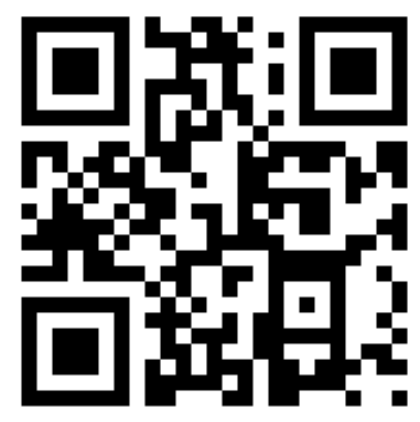

